\title{
The Problem of Interpreting and Receiving Prešeren's Poem To the Poet
}

\author{
Zoran Božič ${ }^{1}$ \\ ${ }^{1}$ Faculty of Humanities, University in Nova Gorica, Slovenia \\ Correspondence: Zoran Božič, Faculty of Humanities, University in Nova Gorica, Vipavska cesta 13, 5000 Nova \\ Gorica, Slovenia. Tel: 386-31-229-437. E-mail: zoran.bozic@guest.arnes.si
}

Received: July 3, 2014 Accepted: September 6, 2014 Online Published: November 25, 2014

doi:10.5539/ells.v4n4p8 URL: http://dx.doi.org/10.5539/ells.v4n4p8

\begin{abstract}
The poem To the Poet represents one of the pinnacles of Prešeren's artistic expression, however, numerous interpreters had difficulties with its extreme pessimism. In accordance with the belief that one should first and foremost recognise "the sharp-sighted eagle" in the first national poet, interpreters tried to revaluate this pessimism with the cult of poetic mission. Empirical reception test demonstrated that the structure of the poem actually enables diverse, even completely illogical understandings of rhetorical questions, most probably on account of psychological influence of negation.
\end{abstract}

Keywords: empirical test, interpretation, Prešeren, reception, To the Poet

\section{Introduction}

France Prešeren (1800-1849) is the most important Slovene (Note 1) poet of romanticism. Although of peasant origin, he completed his doctor's degree in law in Vienna. He worked in Ljubljana as a lawyer's assistant and, due to his free thinking, was permitted by the authorities to open an independent law practice only three years before his death. With his poetry, romantic in contents and classical in form (Romance poetic forms, such as tercina, quartina, octava and sonnet, prevail), the Slovenians established a contact with contemporary European literature. Prešeren's most famous poems are Farewell to Youth, Sonnets of Unhappiness, A Wreath of Sonnets, The Baptism at the Savica, To the Poet, A Toast and The Still Beating Heart.

Already in 1905 a large monument was erected in honour of the poet in the centre of Ljubljana, and later the poet rose to the level of a national legend. Today, the date of his death is the Slovenian cultural holiday, the most important Slovene award for artistic achievements is named after him, and the seventh stanza of $A$ Toast is the Slovene national anthem.

\section{To the Poet - Interpretative Attention Revived}

Prešeren's poem To the Poet is known to almost every secondary school student, being a fixed star in the selection of Prešeren's poems at four-grade secondary schools. Moreover, according to the study by Silvo Fatur on reception of Prešeren's poems, the most successful matura graduates rank To the Poet first both in the number of selections and in terms of popularity (Prešeren, 2000; Božič, 2010, p. 374). This is not a coincidence, since both the contents and the form of the famous poem "represent a key text that opens perspectives backwards and forward across all essential stages in the development arc of Prešeren's conscience as well as his expressive potential" (Paternu, 1960, p. 227).

Consequently it is rather unusual that in the new millennium the research interest for The Baptism at the Savica (cf. Marinčič, 2011; Božič, 2012, 2013 and 2014) still continues, or the scientific curiosity on some receptively demanding Prešeren's sonnet is revived (cf. Bjelčevič, 2013), while in the independent Slovene state, To the Poet has become a less challenging Prešeren's work of art. It is true that a special characteristic of The Baptism is its open text that has often instigated highly opposing explanations by experts on Prešeren and the interpreters themselves have often radically changed their attitudes (Kos, 2001, pp. 81-90), however, exactly the same seems valid for the poem To the Poet. I will try to illustrate and argue this thesis, returning to my own research starting point as stated in my B-diploma work, carried out several decades ago and entitled Motnje pri razumevanju literarnih del (Problems in understanding literary works, Božič, 1975) (Note 2). 


\section{History of Interpretative Approaches}

That the poet himself had difficulties with the poem To the Poet is testified with the fact that it was first published under the title Osrčenje (Emboldening), while in one of the handwritten variants it is recorded with the exact opposite Poet's lament (Prešeren, 1965, p. 243). Prešeren selected a neutral title for publishing in his collection The Poems, however, abandonment of the original title probably means that the poet felt it was not in complete harmony with the overall concept of the poem (Note 3). The thematic contrast between encouragement and lament proves that the contradiction of message (conscious acceptance of suffering itself and its perpetuity) is integrated in the very structure of the poem and, in accordance with this, the history of its interpretative approaches developed too. For an easier access to interpretation the whole poem To the Poet is given, based on its publication in The Poems in 1847:

Kdo zná

noč temno razjásnit, ki tare duha!

Kdo vé

kragulja odgnati, ki kljuje srce

od zora do mraka, od mraka do dné!

Kdo učí

izbrisat 'z spomina nekdanje dni, brezup prihodnjih oduzét spred oči, praznôti ubežáti, ki zdánje morí!

\section{Kako}

bit óčeš poet in ti pretežkó

je v prsih nosít al pekel, al nebo!

\section{Stanu}

se svojega spomni, tŕpi brez miru!

\begin{tabular}{|l|l|}
\hline To whom & Who'll say \\
It is given to lighten the soul-fretting gloom! & How to brighten dark night, which he soul can dismay! \\
Who may & Who'll free \\
$\begin{array}{l}\text { Rout the vulture that seizes the heart for his prey } \\
\text { From dawn unto darkness, from darkness till day! }\end{array}$ & Himself from the heart-piercing hawk's agony \\
& From morning to dusk and through nightly ennui! \\
Who shows & Who'll try \\
$\begin{array}{l}\text { How to blot out the memory of yesterday's woes, } \\
\text { And the eyes before threatening anguish to close, } \\
\text { To flee from today with the irk of its throes! }\end{array}$ & $\begin{array}{l}\text { Re wipe from his mem'ry the days now gone by, } \\
\text { And from today's smoth'ring emptines fly! }\end{array}$ \\
$\begin{array}{l}\text { Thy care } \\
\text { A poet to be is not vain if thou dare } \\
\text { Both heaven and hell in thy bosom to bear! }\end{array}$ & You'll know \\
Nor cease & Either heav'n or hell through thy bosom must flow! \\
To think of thy calling, and grieve without peace! & Anew \\
(translated by Paul Selver) & Recall your vocation, endure it with rue! \\
\end{tabular}

\subsection{Acceptance of the Poet's Suffering}

Although canonization of Prešeren started already in his lifetime (Božič, 2010, p. 247) and Josip Stritar, the very first serious researcher of his poems, wrote that everything seemed "beautiful on him, everything lovable, even 


\subsection{Interpretative Turnabouts of Anton Slodnjak and Boris Paternu}

The interpretations of two leading experts on Prešeren of the 20th century, Anton Slodnjak and Boris Paternu, present a special story. Although Paternu is twenty-five years younger and consequently appears in the role of expert on Prešeren two decades later than Slodnjak (Note 6), both continue with the approach introduced by Župančič, Prijatelj and Žigon. According to Slodnjak's explanation in Pregled slovenskega slovstva (Overview of Slovene literature) Prešeren in To the Poet "overcame his personal grief", his "heart is now between the sky and the earth" and "all the human and earthly sorrow flows through him and divine mercy is poured into him" (Slodnjak, 1934, p. 82). In the article France Prešeren: ob stopetdesetletnici rojstva (France Prešeren: at the hundred and fiftieth anniversary of his birth) he gets even closer to Žigon by maintaining that with the poem To the Poet "the poet ended his 'love period' and started the era of objective lyric in a specific meaning of the word" and that "his poetic task is no longer to seek his personal happiness, but to accept what life offers to him, awakening with his poem, through all the unique, the faith in human beings and declaring his love towards them" (Slodnjak, 1950, p. 619). Very similar is a statement by Paternu in his discussion Petrarca pri Slovencih (Petrarca and Slovenes), that the poet assumed "his promethean artistic mission, accepted a devastating, yet at the same time liberating revelation: to renounce and suffer, and to create beauty, truth, goodness out of the suffering" (Paternu, 1955, p. 248).

The optimistic re-evaluation of the poem To the Poet reached its peak in Paternu's discussion Problem katarze $v$ Prešernovem Pevcu (The problem of catharsis in Prešeren's To the Poet), which was dedicated to the murdered partisan Janina (Note 7) and published in the collection 900 let Kranja (900 years of Kranj). Paternu actually establishes that "every rather responsive reader will admit that the emotional atmosphere accompanying Prešeren's confession is more dark than light", however, at the same time stating that "the most evident thesis related to the poem in itself, regardless of inner contrasts, is positive, truly and deeply encouraging" (Paternu, 1960 , p. 241) and that the poet's consciousness "creates order and meaning out of chaos and paradox, victories out of defeats" (p. 246). Malavašičs's sharp-sighted eagle with strong wings can be recognized in words that Prešeren "in poetry recognizes an orpheic power that preserves the man, liberates him from spiritually empty vegetating, and lifts him up into the world of spiritual richness, beauty and freedom" (p. 238).

Since Paternu recognises "encouragement" rather than the "poet's lament" in the poem, he explains the rhetoric questions which the poet puts in the first three stanzas (p. 232) as follows:

"The basic notional structure of each of the three stanzas is essentially the same. Each stanza presents a related, albeit variant thesis, which could be simply paraphrased as follows:

a) A poet is a person able to overcome the spiritual misery of reality;

b) A poet is a person able to neutralize the emotional depression of everyday life;

c) A poet is a person able to chase away the dark past, empty present, hopeless future.

In short, a poet is a person able to conquer the misery of outer and inner reality of life."

Slodnjak, who in that time lost his position of Slovene literature lecturer at the Faculty of Arts in Ljubljana (Gspan, 1969, p. 195), while Paternu was only just starting his lecturing career at the Department of Slovene studies in Ljubljana, published his monograph Prešernovo življenje (Prešeren's life) four years later. As if he had forgotten that he himself had contributed to optimistic interpretations of the poem To the Poet, in his note he reproaches the length of Paternu's discussion and questions his interpretation of the first three stanzas of the poem:

"Boris Paternu dedicated the most expansive modern discourse to the poem To the Poet in his treatise The problem of catharsis in Prešeren's To the Poet, published in the collection 900 years of Kranj, 1960, pp. 226-249. His interesting, albeit too expanded argumentations - to interpret a text, containing 62 words, over 8000 words are spent - obviously conceived as dialectic criticism of Žigon's mystic interpretations, are not convincing, since the author misunderstood and paraphrased the first three stanzas. He namely transposed their contents into the words: 'The poet is the one who manages to overcome the misery of outer and inner reality of life.' Needless to prove that the paraphrase is violent and 'counter-Prešeren-wise', since the whole poem categorically dictates our perception of the first three stanzas as desperate calls to which no answer exists. The answer as discerned by Paternu is actually the least probable." (Slodnjak, 1964, p. 314)

Slodnjak is certainly right when stating that there are no answers to the "desperate calls" in the first three stanzas of the poem To the Poet. In the opposite case, the last two stanzas that express acceptance of suffering would be meaningless. Slodnjak's statement met with no public response, however, ten years later Paternu published his unchanged study on To the Poet in Pogledi na slovensko književnost I (Views on Slovene literature I), but 
without dedication (Paternu, 1974). The next year, Dimitrij Rupel presented his reflections on The Baptism at the Savica, which he entitled Slovenski kulturni sindrom (Slovene cultural syndrome) (Note 8). In it Rupel, who is obviously not aware of Slodnjak's note, persists in marking Prešeren as a sharp-sighted eagle: "The poet is god, is work is holy, his gift is a divine gift ... /.../ The poet has the power 'to lighten the soul-fretting gloom', 'rout the vulture that seizes the heart for its prey', 'how to blot out the memory of yesterday's woes, And the eyes before threatening anguish to close, To flee from today with the irk of its throes'." (Rupel, 1975, p. 108).

The same year, not being familiar with Slodnjak's argumentation, I contended that "nobody" is the only possible answer to the rhetorical questions of the first three stanzas To the Poet, as stated in the above-mentioned diploma work. With such a meticulous researcher as Paternu there can be no doubt that during his preparations for the monograph France Prešeren in njegovo pesniško delo (France Prešeren and his poetic work) he read Slodnjak's notes and examined diploma works that opposed to findings of his study. Therefore it is much more surprising that in the second part of this monograph, in which he modified his former interpretation of To the Poet, gradually returning to Prešeren as a wounded and chased swan, he did not refer to publicly presented findings of other experts on Prešeren, but simply ignored them: "Experiences in the literary-historic seminar have shown that even study readings differ at this point, ranging from: 'It is the poet who can lighten the soul-fretting gloom' to the completely opposite option: 'Nobody can lighten the soul-fretting gloom'.” (Paternu, 1977, p. 156).

Paternu's interpretative circle closes after the independence of Slovenia, when there is really no more need to artificially turn the pessimistic Prešeren into an optimistic Koseski. Although he questions his own research findings when mentioning his research history, in his monograph France Prešeren 1800-1849 (Note 9), his interpretation of the poem To the Poet gets closer to Slodnjak's interpretation again:

"Who! in the poem that is called and that should master and remove the suffering, is graphically alienated in the introductory lines of the three stanzas, it is the subject that is looked for, absent and anonymous, it can be the one who exists nowhere, it can also be a Nobody. Some optimistic explanations covertly introduced to this Whom the poet's personal orpheic power that is supposed to be all-powerful. But in this case there would be no reason for the poem to continue or to break into its second and different conclusion made of two stanzas, in which the substantive flow takes another turn." (Paternu, 1994, p. 167)

\section{The Poet Is Obliged to Accept the Very Hell and Its Endlessness!}

At this point I complement my previous explanation of the poem To the Poet with the finding that none of the many interpreters that describe the poet's existence being torn between "hell" and "heaven" failed to notice an important fact, namely that Prešeren explicitly writes that as a poet he has to accept "either hell or heaven", not hell and heaven. To the Poet significantly differs from Goethe's poem Prometheus (Note 10), not only by stating that "with boastful disdain he refuses consolation of gods and with a titanic gesture accepts both suffering and joy" (Paternu, 1977, p. 158), but primarily in the fact that joy, cheerfulness, pleasure, all that is encompassed by the metaphor "heaven", do not exist at all in Prešeren. Thus the message of To the Poet is not that Prešeren as a poet has to accept suffering together with happiness, but that as a poet he has to accept the sole "hell", i.e. nothing but suffering without a moment of happiness. Only that explains his conclusion: “... grieve without peace!".

\section{Empirical Reception Test of the Poem To the Poet in Secondary School Students, Slovene Language Experts and Students}

In view of the fact that during the many years of my pedagogical practice I often dealt with the interpretation of the poem To the Poet, I started, quite some years ago, to test how the rhetorical questions are understood by secondary school students, and whether the differing views of literary historians are connected with the reception of the poem in mass readers. These perspectives were complemented with a questionnaire on the slovlit on-line forum, where fellow Slovene language experts voiced their views, and with a study among Slovene language students at the Faculty of Arts in Ljubljana.

Years ago I surveyed forty-five students of economic grammar school and found that prevalent answers to the question To whom / It is given to lighten the soul-fretting gloom! etc. were love, me/myself, the poet, a friend and God, very rarely did students mention the option "nobody". The survey was repeated with the last two generations and most students opted for the poet and God, only two answered "nobody". So on the one hand, they agreed with Paternu's interpretation of 1960, on the other hand with Rupel's interpretation of 1975.

Thirty-two colleagues participated in the on-line survey. As many as eighteen answered nobody, twelve the poet and one poetry. Obviously, the majority of them answered under the influence of literary historical studies (primarily Slodnjak's Prešeren's life and Paternu's monograph France Prešeren and his poetic work, which they 
were familiar with from their studies), while at least some who teach at the secondary level may reflect the influence of my school interpretation of the poem To the Poet in the textbook Književnost $v$ četrtem letniku srednje šole (Literature in the fourth grade of secondary school) (Božič, 1996, p. 273).

The viability of such explanation has been confirmed by a survey among Slovene language students in the second Bologna cycle at the Faculty of Arts in Ljubljana; professor Alenka Žbogar helped me carry it out. Considering the fact that Slovene studies in Ljubljana have no systematic lectures on Prešeren, students' answers are not "compromised" by professional literature and closely resembled the answers of secondary school students. Twenty-two students took part: seventeen answered the poet, only five wrote nobody.

It can be established that the empirical study of the reception of the poem To the Poet confirms that in mass readers misleading understandings of the first three stanzas are possible, as presented in detail in the interpretative section of the discussion. Since this cannot be explained by readers wanting, out of national feelings, to artificially create an optimistic Prešeren, a different explanation has to be found.

\section{Denial as an Interpretative Need}

It can be presumed that understanding of the poem To the Poet, which actually has a horrible, extremely masochistic message, involves a sort of protective mechanism, connected with the necessity of survival. This is a psychological method of denial or, according to Freud, an "unconscious protective mechanism against external threats (such as information) that jeopardize an individual self" (Salecl, 2012). An individual can deny their own illness or difficulties in their love life, while in modern times this is often done by political elites or multinational companies that have caused some environmental catastrophe.

Denial of the pessimist message in the poem To the Poet can be explained with an intertextual comparison, namely with Camus's questioning of the relationship between the investigative judge and Meursault in the novel The Stranger. Meursault, charged of a murder, remains totally indifferent during hearings and calmly reveals the judge that he does not believe in God. The investigator, completely losing his mind, starts yelling and, with a crucifix in his hand, begins threatening the accused with the argument that his godlessness takes away the meaning of the investigator's life as well (Božič, 1998, p. 114). Something similar might happen to mass readers of the poem To the Poet: if they accept the thesis that the life is sole and constant suffering, then they also lose any trace of hope.

\section{Conclusion}

It can be concluded that a combination of interpretative and empirical approach to dealing with classical poetry proves to be productive. Not that an empirical reception test should replace an independent interpretation of a literary scientist or even refute it, but primarily in order to shed additional light on and widen the problem-oriented basis for our research findings.

\section{References}

Aškerc, A. (ed.). (1900). Prešernov album (1800-1900). Ljubljana: Ljubljanski zvon.

Bjelčevič, A. (2013). Julija je stopila v »cerkev razsvetljeno«: k Žigonovi razlagi Prešernovega soneta Je od vesel'ga časa teklo leto. Slavistična revija, 61(4). 591-604.

Božič, Z. (1975). Motnje pri razumevanju literarnih del. Diploma work. Ljubljana: Oddelek za primerjalno književnost, Filozofska fakulteta.

Božič, Z. (1996). France Prešeren: Pevcu (recording of a lesson). In V. Cuderman (Ed.), Književnost v četrtem letniku srednje šole. Ljubljana: Zavod republike Slovenije za šolstvo.

Božič, Z. (1998). Poljub zlata: delovni zvezek za domače branje. Ljubljana: DZS.

Božič, Z. (2010). Slovenska literatura $v$ šoli in Prešeren. Ljubljana: Tangram.

Božič, Z. (2012). Problem kvadrature Krsta: Prešernova pesnitev kot izraz kulturne neenakovrednosti. Serbian studies research, 3(1). 169-181.

Božič, Z. (2013). France Prešeren's Poems: from Misunderstanding to Teaching. Interlitteraria, 18(1), 90-107. http://dx.doi.org/10.12697/IL.2013.18.1.07

Božič, Z. (2014). France Prešeren's poems: understanding, evaluation, interpretation: reception-based approach to the poetry of the most important Slovenian romantic poet. Saarbrücken: LAP Lambert Academic Publishing.

Celestin, F. (1882). France Preširen. Zagreb: self-published. 
Goethe, J. W. (1950). Prometej. Novi svet, 5(1), 48-49.

Gspan, A. (1969). Anton Slodnjak - sedemdesetletnik. Jezik in slovstvo, 14(7), 193-195.

Jurić, I. J. J. (1891). Ljubezen v Petrarkovih rimah z ozirom na slovenskega lirika - prvaka. Rimski katolik, 3, 269-275, 314-322, 369-379.

Kos, J. (2001). Krst pri Savici v luči kritik in interpretacij. France Prešeren: Kerst per Savizi. Celje: Mohorjeva družba. 71-96.

Mahnič, A. (1887). Dvanajst večerov: pogovori doktorja Junija z mladim prijateljem. Gorica: self-published.

Malavašič, F. (1847). Slovensko pesništvo: Prešerin in Koseski. Kmetijske in rokodelske Novice, 5(8), 32.

Marinčič, M. (2011). Križ nad slovansko Trojo: latinski palimpsesti v Prešernovem Krstu pri Savici. Ljubljana: Slovenska matica.

Paternu, B. (1955). Petrarca pri Slovencih. Naši razgledi, 4(10), 246-248.

Paternu, B. (1960). Problem katarze v Prešernovem Pevcu. In J. Žontar (Ed.), 900 let Kranja: spominski zbornik. Kranj: Občinski ljudski odbor (pp. 226-249).

Paternu, B. (1974). Pogledi na slovensko književnost I: študije in razprave. Ljubljana: Partizanska knjiga.

Paternu, B. (1977). France Prešeren in njegovo pesniško delo II. Ljubljana: Mladinska knjiga.

Paternu, B. (1994). France Prešeren 1800-1849. Ljubljana: Dr. Anton Kovač.

Prešeren, F. (1965). Zbrano delo I. Janko Kos (ed.). Ljubljana: Državna založba Slovenije.

Prešeren, F. (2000). Kam?: izbor Prešernovih pesmi. Silvo Fatur (ed.). Koper: Knjigarna Libris.

Prijatelj, I. (1905). Drama Prešernovega duševnega življenja. Naši zapiski, 4(10-11), 157-183.

Rupel, D. (1975). Slovenski kulturni sindrom. Sodobnost, 23(2), 97-109.

Salecl, R. (2012). Zanikanje in nova slepota. Delo (Sobotna priloga), 6. 10. 2012. 32.

Slodnjak, A. (1934). Pregled slovenskega slovstva. Ljubljana: Akademska založba.

Slodnjak, A. (1950). France Prešeren: ob stopetdesetletnici rojstva. Nova obzorja, 3(10), 609-620.

Slodnjak, A. (1964). Prešernovo življenje. Ljubljana: Mladinska knjiga.

Stritar, J. (1866). Preširnovo življenje; Preširnove poezije. Pesmi Franceta Preširna, s pesnikovo podobo, z njegovim životopisom in estetično-kritičnim uvodom. Ljubljana: H. Ničman. 3-46.

Terseglav, F. (1905). Problemi v Krstu pri Savici. Slovenec (Prešernova priloga), 9. 9. 1905.

Župančič, O. (1946). Prešeren in današnji dan. Novi svet, 1(1-4), 3-8.

\section{Notes}

Note 1. Slovenia is a Central European country, situated in a triangle between the Alps, the Pannonian Plain and the Adriatic Sea. Slovenians are the westernmost Slavic nation, having borders with Italians, Germans in Austria, and Hungarians. For many centuries they lived within the Habsburg monarchy; during the twentieth century they belonged to the Kingdom of Yugoslavia and, after the Second World War, to the Socialist Federal Republic of Yugoslavia. Since 1991 they have lived in an independent state.

Note 2. In my assignment at the Department of Comparative literature, I critically evaluated some scientific statements of my professors Franc Zadravec, Boris Paternu and Dušan Pirjevec and later won Prešeren's award for it.

Note 3. Srečko Kosovel had a similar problem in a later period, when he first concluded his famous poem Ekstaza smrti (Extasy of Death) with the line "Europe is dying, Russia is rising", but later the optimistic end, which was not in line with the title and the contents of the poem, was blotted out.

Note 4. Selver's English translation of the poem To the Poet was first published in 1954, and later in five selections of Prešeren's poems, the latest published in 2008. The second translation was contributed by Tom Priestly and Henry Cooper in 1999. There is an important difference in the translation of the fourth stanza that originally reads "Kako / bit očeš poet in ti pretežko / je v prsih nosit al pekel, al nebo!" While Selver, similarly to some translators into other languages, diverges from the original text and writes: "Both heaven and hell ...", Priestly in Cooper more closely follow the original by translating "Either heav'n or hell ...". 
Note 5. Anton Mahnič, who actually admitted a high artistic value of Prešeren's poems, in his Dvanajst večerov (Twelve evenings) wrote for example: "In a golden, artistically crafted dish, Prešeren offers us the poison of sinful passion." (note quote: 155).

Note 6. Slodnjak in the middle of the 1930s, and Paternu in the middle of the 1950s.

Note 7. "This study on Prešeren's faith in life is dedicated to the woman partisan Janina, who in the dark days of occupation gave so much light and true faith to us, the youngest." (Paternu, 1960, p. 226) The dedication reveals the psychological and sociologic basis of Paternu's interpretative optimism.

Note 8. Although Boris Paternu's considers it a "very quick, reduced and completely pragmatic reading" (Paternu, 1977, p. 94), the discussion on Črtomir's conversion has remained interesting until today, as it helped Rupel pave the path to his own political career.

Note 9. It involves a clearly developed message of the monograph title: France Prešeren 1800-1838, by France Kidrič.

Note 10. "Here I sit, forming people / In my image; / A race, to be like me, / To suffer, to weep, / To enjoy and delight themselves, / And to mock you - / As I do!!” (Goethe, 1950, p. 48/49; English version: Wikipedia).

\section{Copyrights}

Copyright for this article is retained by the author(s), with first publication rights granted to the journal.

This is an open-access article distributed under the terms and conditions of the Creative Commons Attribution license (http://creativecommons.org/licenses/by/3.0/). 